\title{
Adrenal Cancer Clinical TNM Finding v7
}

National Cancer Institute

\section{Source}

National Cancer Institute. Adrenal Cancer Clinical TNM Finding v7. NCI Thesaurus. Code C89411.

A clinical finding about one or more characteristics of adrenal cancer, following the rules of the TNM AJCC V7 classification system. Clinical examination and radiog raphic imaging are required to assess the size of the primary tumor and the extent of disease, both local and distant. Biochemical studies should be performed to evaluate the functional status of the tumor. (from AJCC 7th Ed.) 